\title{
Spatio-temporal distribution and biomass of Benthosema pterotum (Pisces: Myctophidae) in the shelf region of the East China Sea
}

\author{
Chiyuki Sassa $^{1, *}$, Youichi Tsukamoto ${ }^{1}$, Keisuke Yamamoto ${ }^{2}$, Muneharu Tokimura $^{3}$ \\ ${ }^{1}$ Seikai National Fisheries Research Institute, Fisheries Research Agency, 1551-8 Taira-machi, Nagasaki 851-2213, Japan \\ ${ }^{2}$ National Research Institute of Fisheries and Environment of Inland Sea, Fisheries Research Agency, 2-17-5 Maruishi, \\ Hatsukaichi, Hiroshima 739-0452, Japan \\ ${ }^{3}$ Japan Sea National Fisheries Research Institute, Fisheries Research Agency, 1 Suidou-cho, Niigata 951-8121, Japan
}

\begin{abstract}
We examined the spatio-temporal distribution and biomass of Benthosema pterotum, a dominant mesopelagic-boundary myctophid in the shelf region of the East China Sea, based on data from seasonal bottom-trawl surveys. They are a major prey item for commercially important demersal fishes in this area. A total of 980000 individuals with a wet weight of $554 \mathrm{~kg}$ were collected from 694 bottom-trawl net samples. Dense distributions $\left(>10^{5}\right.$ ind. $\left.\mathrm{km}^{-2}\right)$ of $B$. pterotum were observed mainly in the area south of Cheju Island in all seasons, where a persistent cyclonic eddy occurs. The distribution pattern indicated the presence of an independent population completing their life cycle in the area south of Cheju Island. Daytime habitat depth of $B$. pterotum (mainly 40 to $90 \mathrm{~m}$ depth) was a markedly shallower depth than previous reports for adult fishes for the family Myctophidae. The mechanism of population maintenance of this mesopelagic species in such a shallow area was hypothesized to be related to the presence of highly turbid waters in the benthopelagic layer, which produces dim light conditions during the daytime. The biomass of B. pterotum in the area south of Cheju Island was estimated to range from 3900 to $38400 \mathrm{t}$.
\end{abstract}

KEY WORDS: Population maintenance $\cdot$ Mesopelagic-boundary myctophid $\cdot$ Benthosema pterotum Biomass $\cdot$ Highly turbid waters $\cdot$ Continental shelf region $\cdot$ Mesopelagic species

\section{INTRODUCTION}

Information on the spatio-temporal distribution and dynamics of key species is essential to understand the structure and dynamics of the entire marine ecosystem in a region (Garcia \& Cochrane 2005). Myctophid fishes are one of the most abundant and widespread mesopelagic fish groups in the world oceans, except for the Arctic Ocean, typically found at depths from 200 to 1000 m during the daytime (Gjøsæter \& Kawaguchi 1980, Brodeur \& Yamamura 2005). Because of their numerical dominance in the fish assemblage, their high biomass, and their trophic importance as a major prey item for larger animals, myctophids are a key component of oceanic ecosystems (Gjøsæter \& Kawaguchi 1980, Brodeur \& Yamamura 2005). Some species of myctophids occur in association with submerged bottom features such as islands, seamounts, or continental slope regions. Species showing such distribution patterns are defined as 'mesopelagicboundary', 'pseudoceanic', or 'slope water' species in the literature (e.g. Hulley \& Lutjeharms 1989, Reid et al. 1991, Brodeur \& Yamamura 2005). Approximately 20 species of myctophids have been recognized as mesopelagic-boundary species in the world (Kawaguchi 1977, Hulley \& Lutjeharms 1989, Hulley 1992, Kinzer et al. 1993, Brodeur \& Yamamura 2005, De Forest \& Drazen 2009). They are often utilized as prey by pelagic fishes and also demersal fishes in the upper continental slope and lower continental shelf area during their vertical migration (Gartner et al. 1997, 2008, Yamamura \& Inada 2001, De Forest \& Drazen 2009). 
The biomass of myctophids was shown to influence the population dynamics of demersal fishes in the continental slope off northern Japan (Yamamura \& Inada 2001).

Benthosema pterotum is a typical mesopelagicboundary myctophid, widely distributed in the subtropical-tropical waters of the Indo-West Pacific, especially over or near the continental shelves (Gjøsæter 1984, Valinassab et al. 2007, Yamada et al. 2007). They are small-sized, with a maximum body size of ca. $55 \mathrm{~mm}$ standard length (SL), and have a life cycle of 1 yr (Gjøsæter 1984, Dalpadado 1988). An extremely large biomass of B. pterotum (ca. 100 million t) was estimated in the Arabian Sea, and attempts were made to evaluate its potential as a fisheries resource (Gjøsæeter 1984, Valinassab et al. 2007). This species is one of the most abundant myctophids in the East China Sea (ECS), one of the largest marginal seas of the western Pacific, including important fishing grounds for various pelagic and demersal fishes (Seikai National Fisheries Research Institute 2001, Yamada et al. 2007).

In the ECS, Benthosema pterotum occur in the epipelagic layer during the larval stage (Ozawa 1986, C. Sassa unpubl. data). Transformation to the juvenile stage begins at ca. 12 to $13 \mathrm{~mm} \mathrm{SL}$, after which they start diel vertical migrations (Gjøsæter 1984, Ozawa 1986). The juveniles and adults occur in the epipelagic layer at night, and descend to the benthopelagic layer of the continental shelf ( $<200 \mathrm{~m}$ depth) during the daytime, forming dense aggregations (Yamada et al. 2007). The main food items of B. pterotum are zooplankton such as copepods and euphausiids (Dalpadado \& Gjøsæter 1988, Kinzer et al. 1993). During the daytime, B. pterotum are a major prey item for commercially important demersal fishes such as hairtail Trichiurus japonicus, croaker (e.g. Larimichthys polyactis and Pennahia argentata), lizardfish (e.g. Saurida wanieso), and anglerfish Lophius litulon (Mio et al. 1984, Baeck \& Huh 2003, Chiou et al. 2006, Yamada et al. 2007). They are also occasionally heavily consumed by pelagic fishes such as jack mackerel Trachurus japonicus and kawakawa Euthynnus affinis (Chiou \& Lee 2004, Tang 2006). Predated on by both pelagic and demersal fishes, $B$. pterotum is a key species acting as an important link between secondary producers and upper trophic levels in the ecosystem of the ECS. However, there is little information on their distribution and biomass in the ECS based on quantitative data.

Here, we describe the spatio-temporal distribution and biomass of Benthosema pterotum in the ECS, based on data from seasonal bottom trawl surveys during the daytime when they shift down to the benthopelagic layer. We then discuss the mechanism of their persistence in the ECS in relation to physical oceanography and habitat conditions.

\section{MATERIALS AND METHODS}

Study area. Our sampling area consisted of the continental shelf region of the ECS, including the semienclosed Yellow Sea (YS) to the north, between $27^{\circ} \mathrm{N}$ and $37^{\circ} 30^{\prime} \mathrm{N}$, west of $128^{\circ} \mathrm{E}$ (Fig. 1). Based on the regional current system and water mass distribution in the study area, cyclonic eddies are formed in 2 areas: south of Cheju Island with its center at approximately $31^{\circ} 30^{\prime} \mathrm{N}, 125^{\circ} 30^{\prime} \mathrm{E}$ and in the central part of the YS, and upwelling occurs along the south coast of China between $26^{\circ}$ and $30^{\circ} \mathrm{N}$ ( Hu 1984, Yanagi et al. 1996, Longhurst 2006) (Fig. 2a). In these areas, the bottom sediments are mainly composed of fine mud or claysized particles (Saito \& Yang 1994, Hamada 1998, Zhu \& Chang 2000) (Fig. 2b).

Sample collection. Benthosema pterotum were collected during 5 cruises in the study area from 1986 to 1989 and 1991 onboard either the Fisheries Training Vessel (FTV) 'Kumamoto-Maru' (Kumamoto Fisheries High School; 380 t) or the FTV 'Kaiho-Maru' (Okinawa Prefecture; 466 t) (Fig. 1, see Table 1). Depth at sampling sites ranged from ca. 20 to $160 \mathrm{~m}$ during each cruise. Sampling periods were shifted approx. 1 to 2 mo between each cruise to collect seasonal sample series, although they were conducted in 5 different years. Sampling was conducted at 149 to 161 stations from 16 April to 8 June 1988, from 28 May to 20 July 1987 , from 18 August to 12 October 1989, and from 22 October to 14 December 1986 (hereinafter referred to as 'spring', 'early summer', 'late summer', and 'autumn', respectively) (Fig. 1, see Table 1). From 15 January to 4 February 1991 (hereinafter referred to as 'winter'), samples were collected at 79 stations, fewer than the other seasonal samples (Fig. 1). The sampling on all occasions covered similar latitudinal and longitudinal ranges.

Fishes on or near the bottom were captured using a bottom otter trawl net with a $35.2 \mathrm{~m}$ head rope and $46.4 \mathrm{~m}$ ground rope. The net was rigged with bridles and otter boards. The stretched mesh size of the net in the wing was 120 to $150 \mathrm{~mm}$, and decreased progressively to the cod end. The mesh of the cod end and cover net were $33 \times 33 \mathrm{~mm}$ and $9 \times 9 \mathrm{~mm}$, respectively. Although we analyzed Benthosema pterotum collected in both the cod end and cover net together in the present study, more than $95 \%$ of individuals were collected in the cover net.

The sites were trawled during the daytime between sunrise and sunset. Tows lasted $60 \mathrm{~min}$, timed from the setting of the net on the bottom to its retrieval time off the bottom, monitored by an acoustic net monitoring system SCANMAR 600. The towing speed was 3 knots $\left(5.6 \mathrm{~km} \mathrm{~h}^{-1}\right)$. The mean $( \pm \mathrm{SD})$ wingspreads and height of the net were acoustically measured by SCANMAR 600 to be $19.9 \pm 1.4 \mathrm{~m}$ and $4.4 \pm 0.4 \mathrm{~m}$, respectively. A 

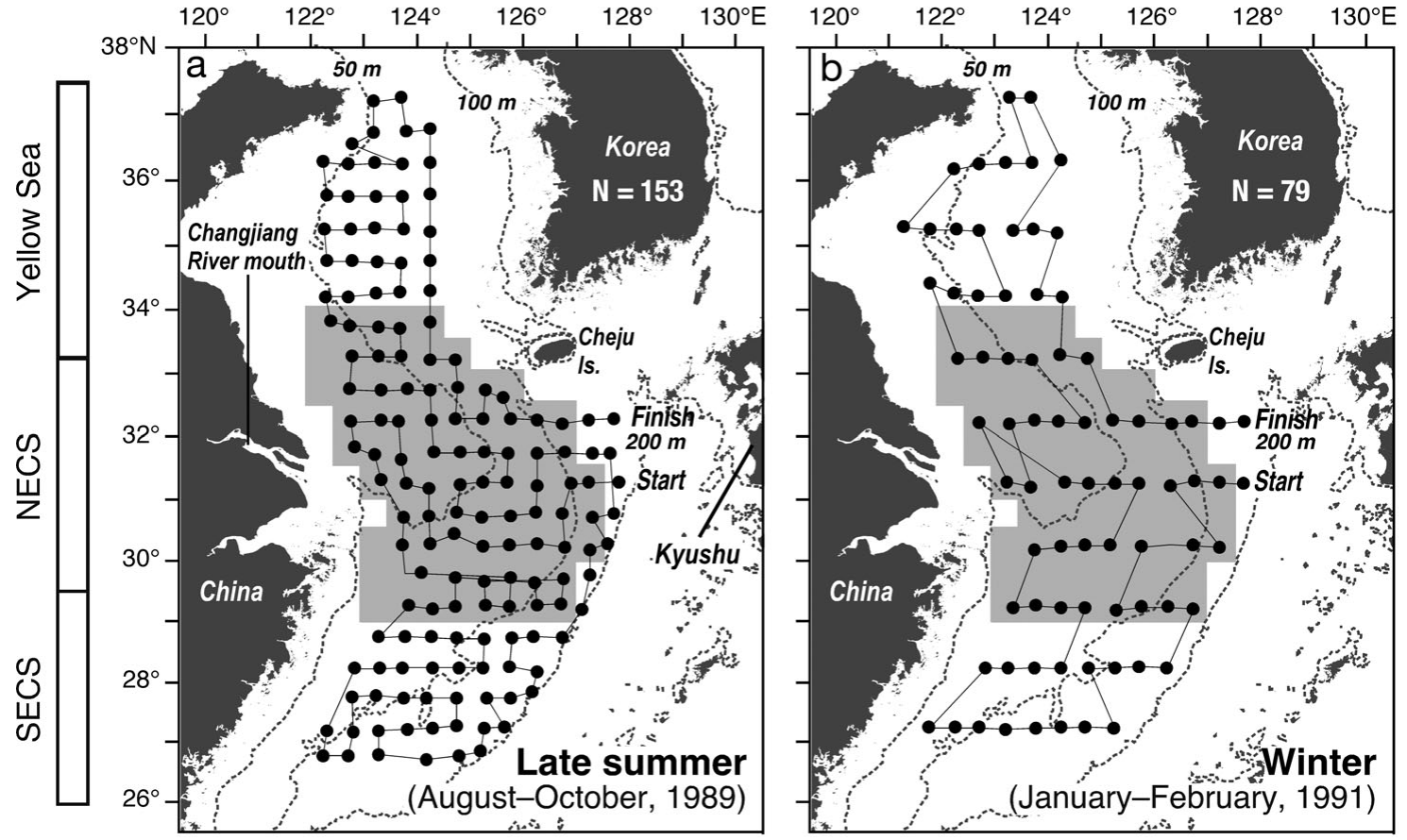

Fig. 1. Benthosema pterotum. Examples of routes taken during survey cruises (Start to Finish) and sampling localities (•) in the East China and Yellow seas during (a) late summer (18 August to 12 October 1989) and (b) winter (15 January to 4 February 1991), with the 50, 100, and $200 \mathrm{~m}$ isobaths (dashed lines). Area where the biomass of B. pterotum was calculated (ca. $210000 \mathrm{~km}^{2}$ ) is shown in light gray. NECS: northern East China Sea; SECS: southern East China Sea; N: total number of sampling stations
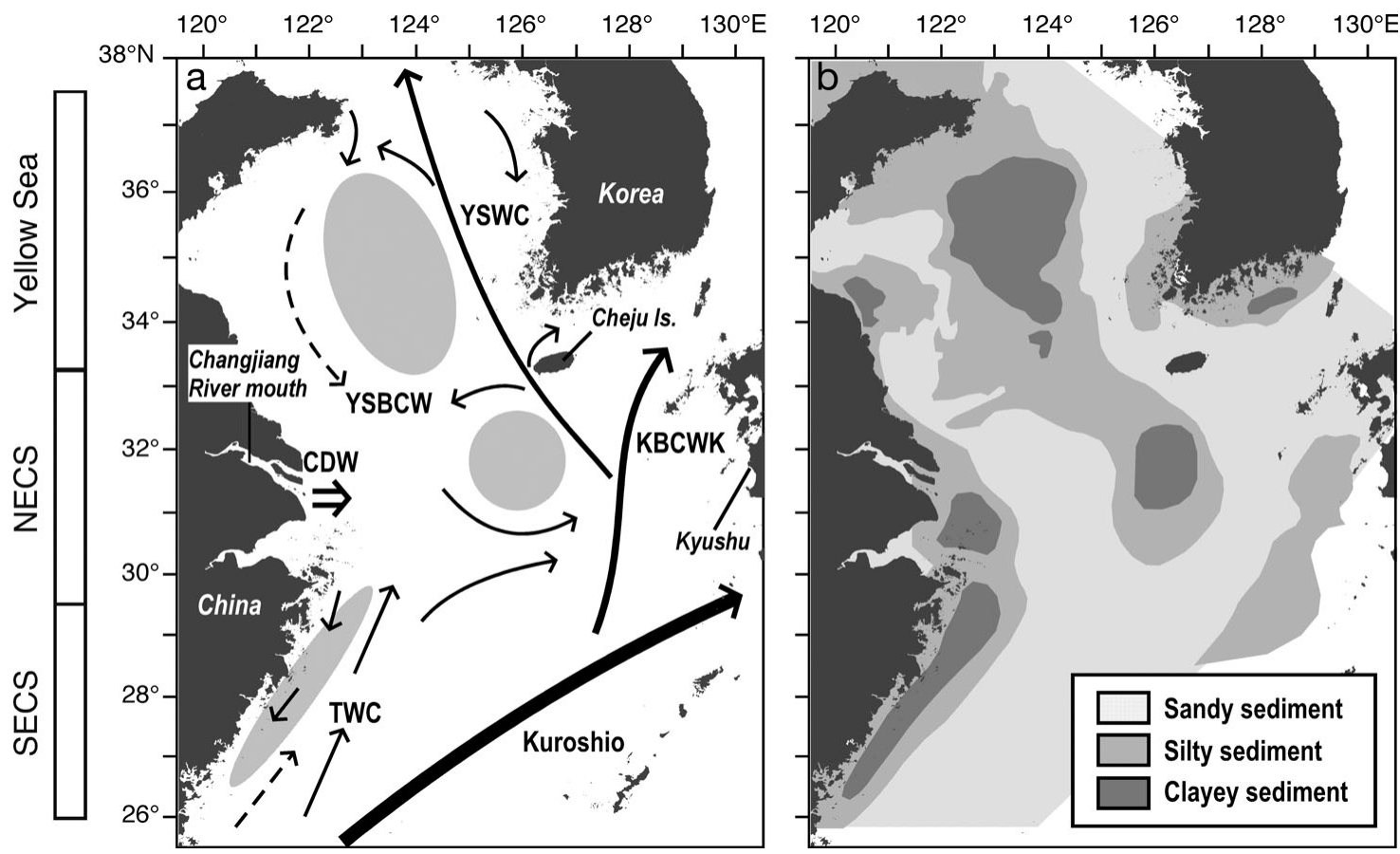

Fig. 2. (a) Current systems and position of eddies (upper 2 gray ovals) and upwelling area (lower gray oval) (modified from Hu 1984). (b) Bottom sediment types and their distribution pattern (modified from Saito \& Yang 1994). KBCWK: Kuroshio Branch Current west of Kyushu; TWC: Taiwan Warm Current; YSBCW: southward spreading of the Yellow Sea Bottom Cold Water; YSWC: Yellow Sea Warm Current; CDW:Changjiang River diluted water; NECS: northern East China Sea; SECS: southern East China Sea 
memory CTD profiler (Alec Electronics) cast was made at each sampling station from the surface to within ca. $5 \mathrm{~m}$ of the bottom. However, we have no salinity data for the autumn survey due to a problem with the CTD. To compensate for this, we refer to the results of Tanaka (1992) that described the salinity field in the bottom layers of our study area, based on data from an oceanographic survey from 12 October to 3 November 1986 using another research vessel.

Benthosema pterotum were counted and weighed on board. If the total fish catch by the cover net was too large to sort at sea, up to $3 \mathrm{~kg}$ of specimens were randomly sampled after measuring the total weight, stored in a plastic bag, and frozen. In the laboratory, B. pterotum were sorted from the quantitative subsamples, and counted and weighed for extrapolation of the total catch.

Data analysis. Density and biomass of the fishes were estimated based on the swept area (110148 \pm $9061 \mathrm{~m}^{2}$, mean $\pm \mathrm{SD}$ ) calculated from the wingspreads of the nets and the towing distance. Since mesopelagic fishes are usually most concentrated when they are in the deep scattering layer (DSL) during the day (Gjøsæter \& Kawaguchi 1980), the biomass estimation based on samples collected in the daytime DSL near bottom would be appropriate. In the study area, the DSL was observed only near the bottom layers during the daytime based on acoustic surveys (C. Sassa \& Y. Tsukamoto unpubl. data), i.e. it would contain the target species. Submersible observations over the continental slopes have documented the occurrence of large aggregations of mesopelagic fishes near the bottom, forming a layer extending from a few centimeters to usually $<10 \mathrm{~m}$ above the substrate in the continental slope of the North Atlantic (Auster et al. 1992, Gartner et al. 2008).

Mean body weight of Benthosema pterotum is defined as the proportion of the catch wet weight to the number caught during each season. Average body length of $B$. pterotum during each season was estimated from the mean body weight using the following relationship (Ishihara et al. 1995): $y=0.0058645 x^{3.2304}$ $\left(\mathrm{r}^{2}=0.978\right)$, where $y$ is body weight $(\mathrm{mg})$ and $x$ is SL (mm).

To compare the distribution of Benthosema pterotum among geographic regions, we categorized our study area into the following 3 sub-areas (Fig. 1): the YS between $37^{\circ} 30^{\prime} \mathrm{N}$ and $33^{\circ} 15^{\prime} \mathrm{N}$, the northern ECS (NECS) between $33^{\circ} 15^{\prime} \mathrm{N}$ and $29^{\circ} 30^{\prime} \mathrm{N}$, and southern ECS (SECS) between $29^{\circ} 30^{\prime} \mathrm{N}$ and $26^{\circ} \mathrm{N}$. We refer to the area shallower than $100 \mathrm{~m}$ depth as the shelf region, and the area between 100 and $200 \mathrm{~m}$ depth as the lower shelf region (Fig. 1).

Quotient analyses (Ibaibarriaga et al. 2007, Neira \& Keane 2008) were performed on data of Benthosema pterotum densities (ind. $\mathrm{km}^{-2}$ ) across all 5 surveys combined to describe selection of habitat in terms of bottom depth $(\mathrm{m})$, temperature $\left({ }^{\circ} \mathrm{C}\right)$, and salinity in the bottom layer. For these analyses, square root-transformed densities of $B$. pterotum within each $10 \mathrm{~m}$ depth interval, $2^{\circ} \mathrm{C}$ temperature, and 0.5 salinity classes were expressed as a percentage of total density, divided by the percentage frequency of stations under each bottom depth, temperature, and salinity, respectively. Quotients $>1$ indicate positive habitat selection, i.e. range of optimum depth, temperature, and salinity.

The weighted mean depth, temperature, and salinity ( $D_{\mathrm{m}}, T_{\mathrm{m}}$, and $S_{\mathrm{m}}$, respectively) of Benthosema pterotum habitat were calculated using the following equations for each sampling period:

$$
\begin{aligned}
& D_{m}=\sum_{i=1}^{n}\left(b_{i} \times d_{i}\right) / \sum_{i=1}^{n} b_{i} \\
& T_{m}=\sum_{i=1}^{n}\left(b_{i} \times t_{i}\right) / \sum_{i=1}^{n} b_{i} \\
& S_{m}=\sum_{i=1}^{n}\left(b_{i} \times S_{i}\right) / \sum_{i=1}^{n} b_{i}
\end{aligned}
$$

where $b_{i}$ is the density (ind. $\mathrm{km}^{-2}$ ) of $B$. pterotum in the $i$ th sampling station, and $d_{i r} t_{i}$ and $s_{i}$ are the bottom depth, water temperature, and salinity in the bottom layer at the $i$ th sampling station, respectively. Prior to the analysis, $b_{i}$ was square root-transformed to reduce any bias caused by sampling stations with extraordinarily large catches.

Mean bottom-water temperatures of each season were compared by 1-way ANOVA followed by the Tukey-Kramer post hoc test.

Biomass estimation. The biomass of Benthosema pterotum in the shelf region between $34^{\circ}$ and $29^{\circ} \mathrm{N}$ was estimated (Fig. 1), since our surveys covered almost the entire area of the distribution of this population during the 5 cruises (see 'Results'). For each cruise, the biomass of B. pterotum (B) and its $95 \%$ confidence intervals (CI) were calculated using the following equations:

$$
\begin{gathered}
B=A \times \frac{1}{n} \sum_{i=1}^{n} W_{i} \\
C I=\frac{1.96 \times A \times S D_{W i}}{\sqrt{n}}
\end{gathered}
$$

where $A$ is the area swept (ca. $210000 \mathrm{~km}^{2}$ ), $n$ is number of sampling stations, $W_{i}$ is catch weight $\left(\mathrm{kg} \mathrm{km}^{-2}\right)$ of $B$. pterotum in ith sampling station, and $S D_{W i}$ is $\mathrm{SD}$ of $W_{i}$. Catch efficiency of $B$. pterotum was assumed to be 1 in these calculations.

To establish a biomass range of other values that would be equally valid, we assumed that (1) the catch 
efficiency of the bottom trawl $(Q)$ is 0.2 to 0.5 and (2) the coverage rate of the thickness of Benthosema pterotum aggregation $(P)$ is 0.44 to 0.88 (see 'Discussion: Limitations in sampling'). The corrected biomass of $B$. pterotum $\left(B^{\prime}\right)$ was calculated using the following equation for each cruise:

$$
B^{\prime}=\frac{B}{Q \times P}
$$

To estimate the minimum and maximum $B^{\prime}$ values, we used $Q \times P$ values of $0.5 \times 0.88$ and $0.2 \times 0.44$, respectively.

\section{RESULTS}

\section{Oceanographic conditions}

In the NECS, where Benthosema pterotum mainly occurred (see 'Horizontal distribution patterns'), mean temperature in the bottom layer during winter to early summer ranged from 13.5 to $14.6^{\circ} \mathrm{C}$ (Fig. 3). During late summer and autumn, it was 18.4 and $18.8^{\circ} \mathrm{C}$, respectively, significantly higher than temperatures for other seasons (Fig. 3; ANOVA and Tukey-Kramer test: $F_{4,284}=$ $58.57, \mathrm{p}<0.05)$. In the NECS, mean sea surface temperature (SST) was $14^{\circ} \mathrm{C}$ in winter and $25.5^{\circ} \mathrm{C}$ in late summer, and decreased in autumn (Fig. 3). Therefore, the water column mixed vertically in winter to form uniform waters with low temperatures of 13.5 to $14^{\circ} \mathrm{C}$ (Fig. 3). Stratification of the water column was initially observed in spring, and was most prominent in late summer, and was less prominent in autumn.

In the SECS, the mean temperature in the bottom layer in late summer and autumn (18.9 and $18.7^{\circ} \mathrm{C}$, respectively) was comparable to those in the NECS, but the values during winter to early summer were ca. 3 to $4^{\circ} \mathrm{C}$ higher. In the YS, more than half of stations (ca. 56 to $80 \%$ ) were covered with cold water $<10^{\circ} \mathrm{C}$ in the bottom layer in all seasons (Fig. 4). Seasonal change in mean temperature in the bottom layer was small in the YS, ranging from $9^{\circ} \mathrm{C}$ in spring to $10.8^{\circ} \mathrm{C}$ in late summer.

The salinity in the bottom layer tended to be low in the China coast region of the YS and NECS north of $32^{\circ} \mathrm{N}$, and high in the lower shelf region. In the YS, the 32 isohalines in the bottom layer were located in the China coast region close to the $50 \mathrm{~m}$ isobaths during all seasons (Fig. 4). In the NECS, the isohalines extended eastward off the Changjiang River mouth and its extension varied from $124^{\circ}$ to $125^{\circ} 30^{\prime} \mathrm{E}$ among seasons. In late summer when the maximum amount of freshwater inflow is usually observed (Beardsley et al. 1985, Zhang 1996), low salinity waters (<32) covered the widest area of the NECS during the study period,

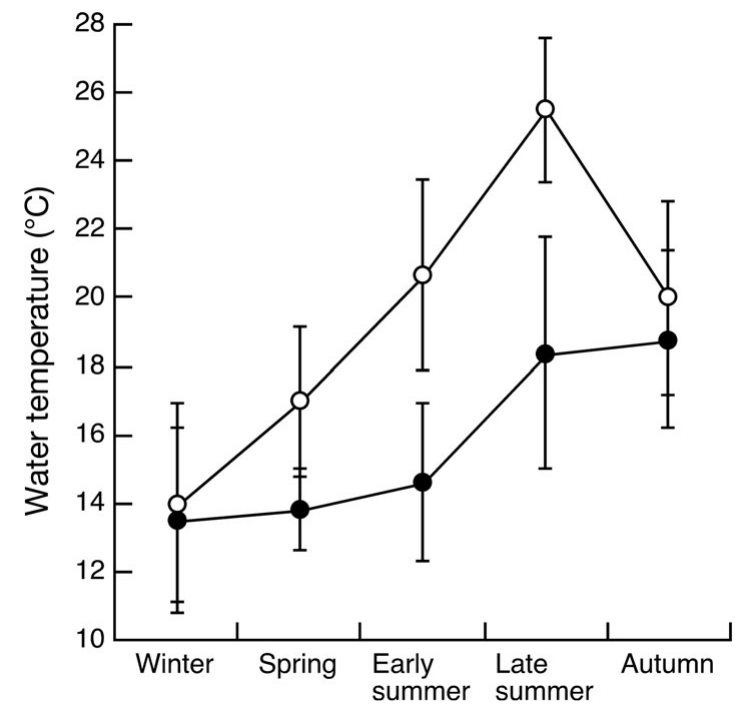

Fig. 3. Mean water temperature in the bottom layer $(\bullet)$ and sea surface temperature (SST) (O) during the 5 cruises in the northern East China Sea (NECS) between $33^{\circ} 15^{\prime} \mathrm{N}$ and $29^{\circ} 30^{\prime}$ N. Error bars represent SD

while the eastward extension of the 32 isohaline in spring was weaker compared to other seasons (Fig. 4). The contours of the temperature and salinity in the bottom layer during each season are given in Sassa et al. (2009).

\section{Seasonal changes in catch and mean body weight}

A total of 980000 individuals with a wet weight of $554 \mathrm{~kg}$ of Benthosema pterotum were collected from the 694 bottom-trawl net samples (Table 1). No other myctophid species was collected in our samplings.

The average densities and wet weights of Benthosema pterotum in the whole study area ranged from 10292 to 16154 ind. $\mathrm{km}^{-2}$, and from 5.6 to $8.5 \mathrm{~kg} \mathrm{~km}^{-2}$, respectively (Fig. 5a,b). Although there were no significant differences in both the densities and wet weights among the 5 cruises (Kruskal-Wallis test: $p>0.1$ ), seasonal trends were observed. Specifically, from autumn to the following late summer, the average densities tended to become lower (Spearman's rank correlation coefficient test: $\mathrm{r}_{\mathrm{S}}=-0.9, \mathrm{p}=0.07$ ), while the average wet weights tended to become higher $\left(\mathrm{r}_{\mathrm{S}}=0.9, \mathrm{p}=\right.$ 0.07) (Fig. 5a,b).

The mean body weight of Benthosema pterotum changed from $0.35 \mathrm{~g}$ in autumn to $0.82 \mathrm{~g}$ in late summer $\left(\mathrm{r}_{\mathrm{S}}=1.0, \mathrm{p}<0.05\right)$ (Fig. 5c). The average body length estimated from the mean body weight increased from $30 \mathrm{~mm}$ SL in autumn to $39.2 \mathrm{~mm}$ SL in late summer (Fig. 5c). Since the spawning season in the study area ranges from summer to autumn 

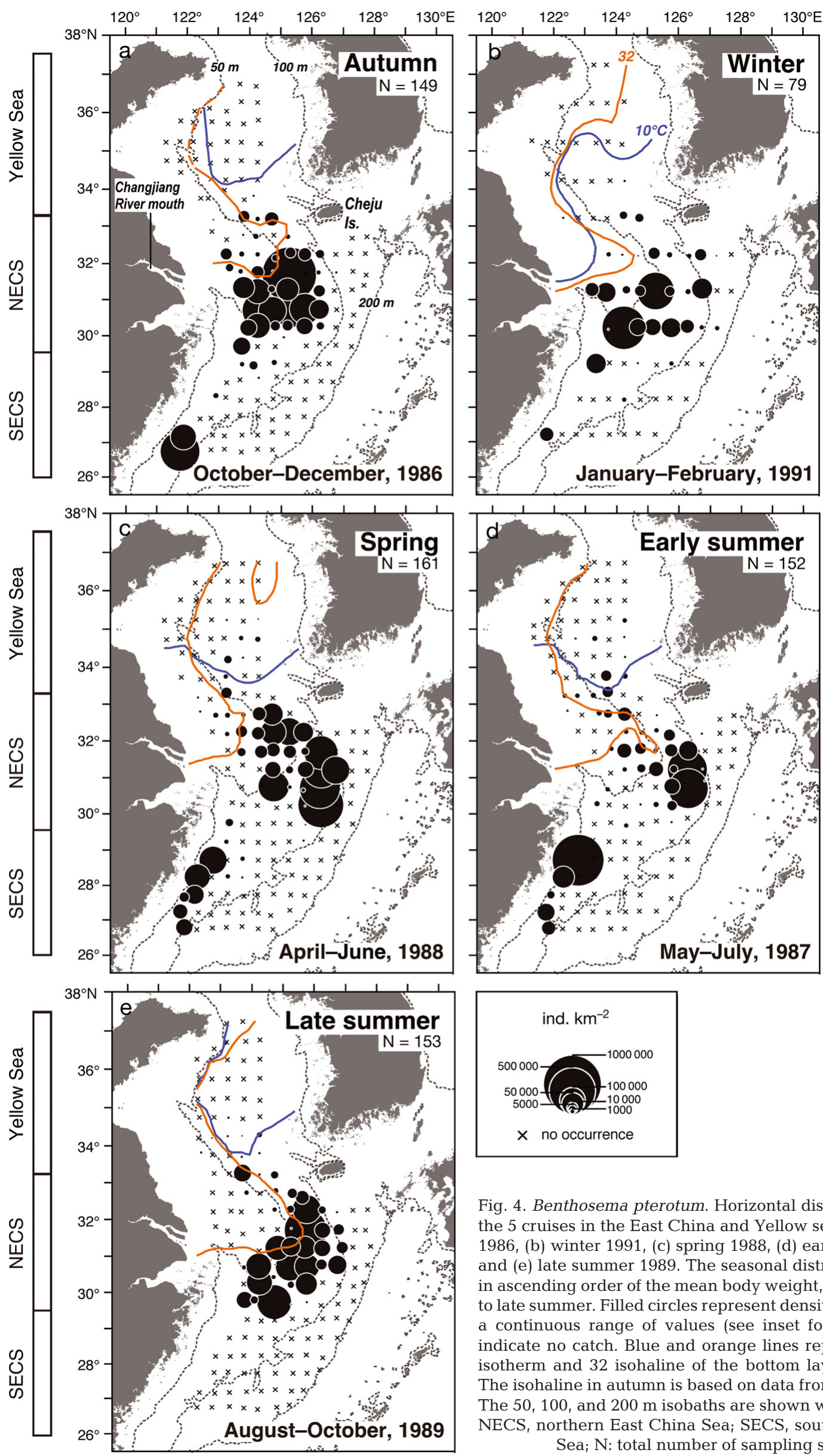

Fig. 4. Benthosema pterotum. Horizontal distributions during the 5 cruises in the East China and Yellow seas in (a) autumn 1986, (b) winter 1991, (c) spring 1988, (d) early summer 1987 , and (e) late summer 1989. The seasonal distribution is shown in ascending order of the mean body weight, i.e. from autumn to late summer. Filled circles represent densities (ind. $\mathrm{km}^{-2}$ ) as a continuous range of values (see inset for scale). Crosses indicate no catch. Blue and orange lines represent the $10^{\circ} \mathrm{C}$ isotherm and 32 isohaline of the bottom layer, respectively. The isohaline in autumn is based on data from Tanaka (1992). The 50,100, and $200 \mathrm{~m}$ isobaths are shown with dashed lines. NECS, northern East China Sea; SECS, southern East China Sea; N: total number of sampling stations 
Table 1. Benthosema pterotum. Sampling period, season, number of samples, total number of individuals and wet weight collected using a bottom otter trawl during 5 cruises in the East China and Yellow seas

\begin{tabular}{|llccc|}
\hline Sampling period & $\begin{array}{c}\text { Sampling } \\
\text { season }\end{array}$ & $\begin{array}{c}\text { No. of } \\
\text { samples }\end{array}$ & $\begin{array}{c}\text { No. of } \\
\text { ind. }\end{array}$ & $\begin{array}{c}\text { Wet wt } \\
(\mathrm{kg})\end{array}$ \\
\hline 22 Oct to 14 Dec 1986 & Autumn & 149 & 267379 & 92.5 \\
28 May to 20 Jul 1987 & Early summer & 152 & 175517 & 119.6 \\
16 Apr to 8 Jun 1988 & Spring & 161 & 248163 & 147.1 \\
18 Aug to 12 Oct 1989 & Late summer & 153 & 173820 & 142.9 \\
15 Jan to 4 Feb 1991 & Winter & 79 & 115374 & 51.9 \\
\hline
\end{tabular}

spring (Table 2). Furthermore mean densities in the NECS were ca. 30 to 200 times higher than those in the YS during all seasons (Table 2).

In the NECS, dense distributions $\left(>10^{5}\right.$ ind. $\mathrm{km}^{-2}$ ) of Benthosema pterotum were mainly observed in the area south of Cheju Island in all seasons (Fig. 4). Few individuals were observed in the lower shelf region of 110 to $160 \mathrm{~m}$ depth, and off the Changjiang River mouth where low-salinity water of 29.5 to 32 usually occurred

(Yamada et al. 2007, C. Sassa unpubl. data), the increase in weight and body length can be correlated directly with growth over the annual life cycle. Although instead of re-sampling the same cohort over a year, different cohorts were sampled in 5 different years, and our analysis was based on the catch data of only large-sized juvenile and adult stages (see 'Discussion: Limitations in sampling'), we consider that our data shows a typical seasonal distribution pattern of $B$. pterotum in the study area.

\section{Optimum daytime habitat environment}

The density quotients of Benthosema pterotum in the 5 surveys showed high values $(>1)$ at the bottom depth between 40 and $90 \mathrm{~m}$, except for values of 0.83 at 70 to $80 \mathrm{~m}$ (Fig. 6a), showing optimum daytime depth range. In contrast, the quotients declined to extremely low values of $<0.1$ at 10 to $30 \mathrm{~m}$ and 100 to $160 \mathrm{~m}$.

For water temperature in the bottom layers, high values of quotients were observed at a broader range between 12 and $24^{\circ} \mathrm{C}$, with peaks at 12 to $16^{\circ} \mathrm{C}$ and 20 to $24^{\circ} \mathrm{C}$ (Fig. 6b). This broader range corresponded with seasonal change in habitat temperature in the bottom layer (see below). On the contrary, the quotients at $<10^{\circ} \mathrm{C}$ exhibited extremely low values of $<0.1$ (Fig. 6b).

For salinity in the bottom layers, the density quotients of Benthosema pterotum showed high values (>1) between 32 and 34, while the values in areas of $<32$ and $>34$ were less than half of the optimum salinity range (Fig. 6c).

\section{Horizontal distribution pattern}

Benthosema pterotum were collected in all 3 subareas, but the mean densities (Table 2) were the highest in the NECS, except for early summer when an extremely large catch $\left(6.6 \times 10^{5}\right.$ ind. $\left.\mathrm{km}^{-2}\right)$ occurred at 1 station of the SECS off the coast of China (Fig. 4). Mean densities in the NECS were ca. 5 to 15 times higher than densities in the SECS during autumn to
(Fig. 4). The distribution center of B. pterotum during spring to late summer was in a slightly more eastern area than during autumn and winter (Fig. 4). In late summer when the low-salinity water $(<32)$ extended eastward from the Changjiang River mouth to
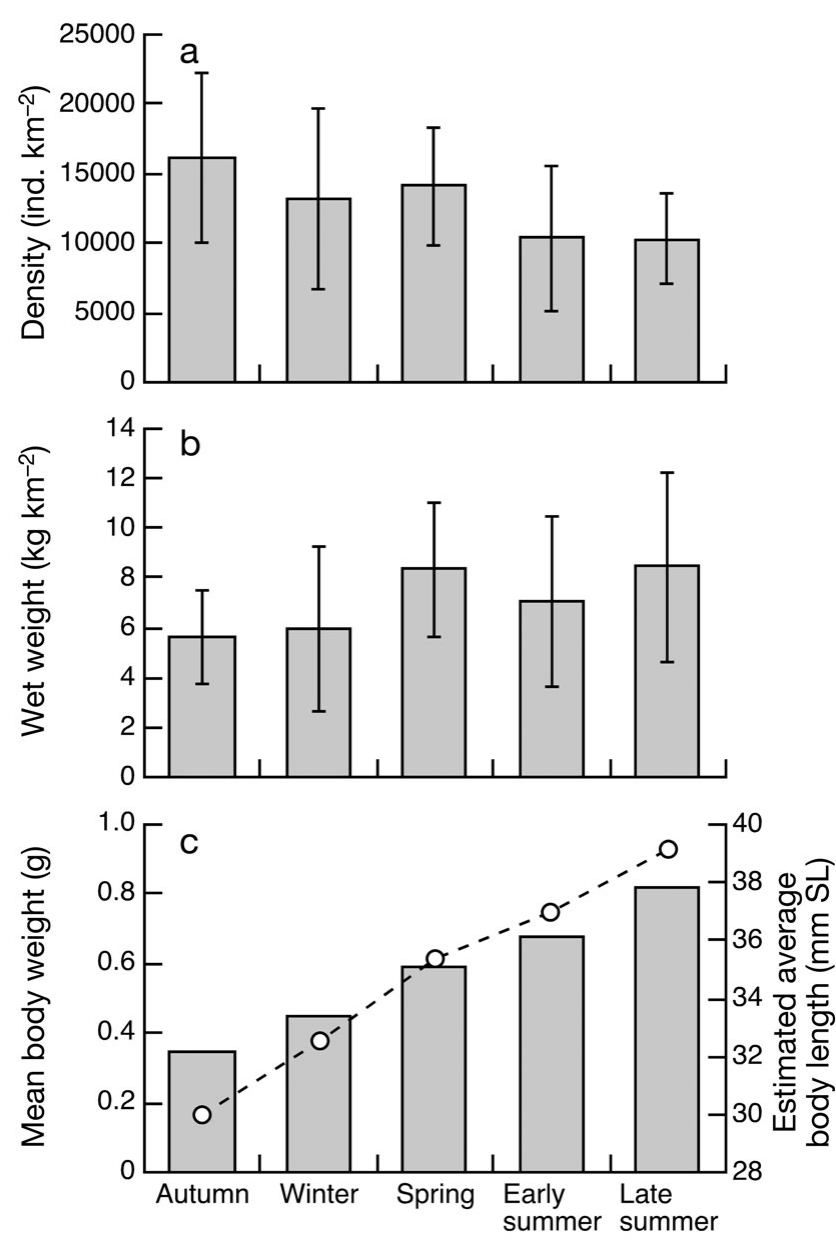

Fig. 5. Benthosema pterotum. Change in (a) density, (b) wet weight, and (c) mean body weight, among seasonal samples collected using a bottom otter trawl in the East China and Yellow seas. Estimated average body length (mm standard length, SL) based on the relationship between body length and wet weight (Ishihara et al. 1995) is also shown (O in c). Error bars represent SE 

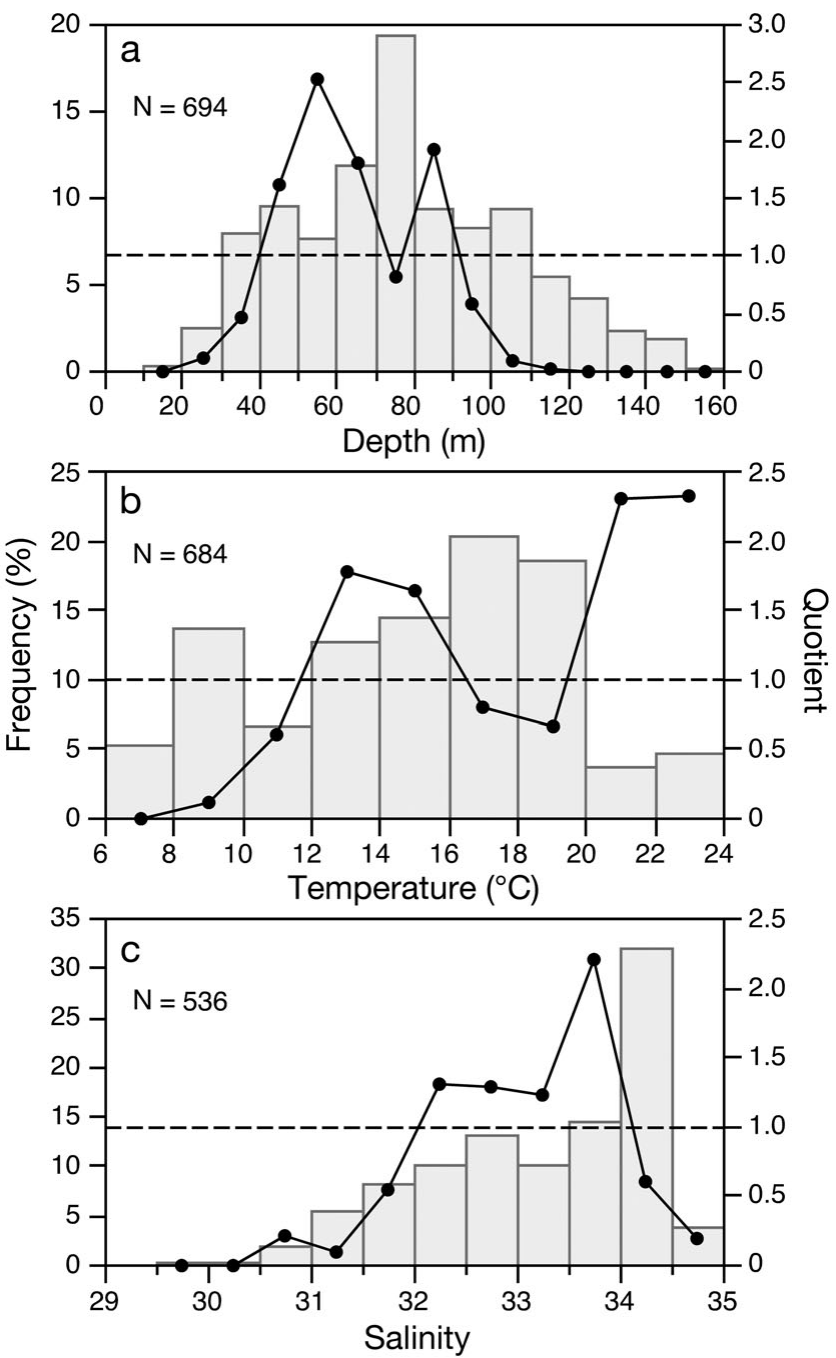

Fig. 6. Benthosema pterotum. Quotient lines of square roottransformed densities (ind. $\mathrm{km}^{-2}$ ) by (a) bottom depth, (b) water temperature in the bottom layer, and (c) salinity in the bottom layer, from combined data obtained across 5 seasonal bottom trawl surveys in the East China and Yellow seas during 1986 to 1991 . The vertical bars correspond to percentage frequency of occurrences of each depth, temperature, and salinity shown along the $x$-axis. Quotient values $>1$ (above the broken line) indicate positive habitat selection. $\mathrm{N}$ : total number of stations analyzed

$125^{\circ} 30^{\prime} \mathrm{E}$, the western side of distribution of B. pterotum slightly shifted east compared to other seasons in the NECS (Fig. 4).

In the SECS, Benthosema pterotum occurred off the south coast of China, and the densities rarely reached $>10^{5}$ ind. $\mathrm{km}^{-2}$, except for late summer (Fig. 4). Finding no B. pterotum in late summer could be due to lack of the sampling effort in the area near the 70 to $80 \mathrm{~m}$ isobath off the Chinese coast where $B$. pterotum were collected in the other seasons (Fig. 4). The distribution between the area south of Cheju Island and the south coast of China was discontinuous in all seasons, except for late summer. In the YS where the bottom layer was covered with cold water $\left(<10^{\circ} \mathrm{C}\right)$ in all seasons, $B$. pterotum was only sporadically found at relatively low densities (Fig. 4).

\section{Seasonal change in habitat environments in the bottom layer}

The daytime weighted mean depth $\left(D_{\mathrm{m}}\right)$ of Benthosema pterotum ranged from 55 to $68 \mathrm{~m}$ in the NECS (Table 3). The $D_{\mathrm{m}}$ during spring to late summer tended to be slightly deeper than during autumn and winter in the NECS, corresponding with the eastward shift of the distribution center (Fig. 4). The $D_{\mathrm{m}}$ in the SECS ranged from 67 to $85 \mathrm{~m}$, which was slightly deeper than in the NECS (Mann-Whitney $U$-test: $\mathrm{p}<0.05$ ).

The weighted mean temperature $\left(T_{\mathrm{m}}\right)$ in the NECS showed seasonal variations, with the highest value of $20.5^{\circ} \mathrm{C}$ in autumn (Table 3 ). It decreased largely to 13.4 to $13.9^{\circ} \mathrm{C}$ during winter to early summer, and increased to $17.4^{\circ} \mathrm{C}$ in late summer, corresponding closely with the seasonal change of water temperature in the bottom layer (Fig. 3). In the SECS, the $T_{\mathrm{m}}$ in autumn $\left(21.1^{\circ} \mathrm{C}\right)$ was comparable to that in the NECS, but the values during winter to early summer were ca. 3 to $4^{\circ} \mathrm{C}$ higher than in the NECS (Table 3).

Among the seasonal samples, no significant difference was observed in the weighted mean salinity $\left(S_{\mathrm{m}}\right)$ in both the NECS and SECS, with values ranging from 32.9 to 33.4 and from 33.9 to 34.3 , respectively (Table 3).

\section{Biomass on the NECS shelf}

The biomass of Benthosema pterotum in the area south of Cheju Island of the shelf region of the NECS was estimated, since our surveys covered almost the entire area of the distribution of this population (Fig. 4). Assuming that the catch efficiency of the trawl is 1 ,

Table 2. Benthosema pterotum. Mean densities (ind. $\mathrm{km}^{-2}$ ) from combined samples collected during the 5 cruises in the East China and Yellow seas. NECS: northern East China Sea; SECS: southern East China Sea; nd: no data

\begin{tabular}{|c|c|c|c|c|c|c|}
\hline \multirow{2}{*}{$\begin{array}{l}\text { Sampling } \\
\text { season }\end{array}$} & \multicolumn{2}{|c|}{ Yellow Sea } & \multicolumn{2}{|c|}{$\longrightarrow$ NECS $\longrightarrow$} & \multicolumn{2}{|c|}{$\longrightarrow$ SECS $\longrightarrow$} \\
\hline & Mean & $\mathrm{SE}$ & Mean & $\mathrm{SE}$ & Mean & $\mathrm{SE}$ \\
\hline Autumn & 255 & 250 & 31223 & 13239 & 8667 & 6707 \\
\hline Winter & 145 & 132 & 29788 & 15159 & 2171 & 1642 \\
\hline Spring & 306 & 176 & 29404 & 9895 & 5707 & 2859 \\
\hline Early summer & 423 & 196 & 12226 & 6785 & 18667 & 16230 \\
\hline Late summer & 738 & 659 & 22920 & 7154 & nd & nd \\
\hline
\end{tabular}


the biomass $(B)$ in this area was estimated to range from $1728 \mathrm{t}$ (95\% CI: $1217 \mathrm{t})$ to 3383 t (95\% CI: 2922 t) (Fig. 7). Although our seasonal samples were taken in different years, the biomass tended to increase from autumn to the following late summer, except for the early summer when the smallest value was observed (Fig. 7). The biomass corrected by the assumption of the catch efficiency and the coverage rate of distribution layers $\left(B^{\prime}\right)$ was estimated to range from 3926 to $38443 \mathrm{t}$ (Table 4).
Table 3. Benthosema pterotum. Daytime weighted mean depth $\left(D_{\mathrm{m}}\right)$, temperature $\left(T_{\mathrm{m}}\right)$, and salinity $\left(S_{\mathrm{m}}\right)$ for each sampling period in the northern (NECS) and southern East China Sea (SECS). We have no salinity data for the autumn survey due to a problem with the CTD. In late summer, no B. pterotum was collected in the SECS; nd: no data

\begin{tabular}{|c|c|c|c|c|c|c|}
\hline \multirow{2}{*}{ Sampling season } & \multicolumn{3}{|c|}{$-\mathrm{NECS}-$} & \multirow[b]{2}{*}{$D_{\mathrm{m}}(\mathrm{m})$} & \multirow{2}{*}{ - SECS } & \multirow[b]{2}{*}{$S_{\mathrm{m}}$} \\
\hline & $D_{\mathrm{m}}(\mathrm{m})$ & $T_{\mathrm{m}}\left({ }^{\circ} \mathrm{C}\right)$ & $S_{\mathrm{m}}$ & & & \\
\hline Autumn & 55.3 & 20.5 & nd & 84.5 & 21.1 & nd \\
\hline Winter & 63.4 & 13.8 & 33.4 & 76.3 & 16.7 & 34.0 \\
\hline Spring & 66.8 & 13.9 & 33.3 & 72.1 & 17.1 & 33.9 \\
\hline Early summer & 66.6 & 13.4 & 33.1 & 67.2 & 17.7 & 34.3 \\
\hline Late summer & 67.5 & 17.4 & 32.9 & nd & nd & nd \\
\hline
\end{tabular}

\section{DISCUSSION}

\section{Limitations in sampling}

In the present study, dense distributions of Benthosema pterotum were observed in the shelf region of the ECS in all seasons; however, there are 3 limitations relating to sampling gear. First, juveniles smaller than ca. $20 \mathrm{~mm}$ SL can be considered to pass through the mesh of the cover net $(9 \times 9 \mathrm{~mm})$, since they are usually collected only in small numbers by the bottom trawl net we used (C. Sassa unpubl. data), although detailed analysis on size selectivity of the net has yet to be carried out. The densities of $B$. pterotum would especially be underestimated largely during autumn to winter when small-sized juveniles are usually collected abundantly in the epipelagic layers at night and the benthopelagic layers during the daytime by the finer meshsize $(<2 \mathrm{~mm})$ net attached to small trawls (C. Sassa unpubl. data).

Second, there is no information on the catch efficiency of Benthosema pterotum by our bottom trawl net (approx. $90 \mathrm{~m}^{2}$ mouth opening). Using a midwater trawl with an opening of approx. $250 \mathrm{~m}^{2}$ and cod end mesh size of $9 \mathrm{~mm}$, the average catch efficiency for $B$. pterotum was estimated to be 0.13 , based on comparisons between acoustic estimates and trawl catches (Gjøsæter 1984). Similarly, Koslow et al. (1997) estimated the catch efficiency of mesopelagic fishes by a midwater trawl $\left(105 \mathrm{~m}^{2}\right.$ mouth opening and $10 \mathrm{~mm}$ cod end mesh) to be 0.07 to 0.14 . Since $B$. pterotum could not escape between the seabed and the ground rope of the trawl, the catch efficiency of the bottom trawl net is expected to be higher than that of the midwater trawl, although there is a possibility of fish escaping from the wings of the trawling net. In some cases, the catch efficiency of demersal fishes is reported to be between 0.2 and 0.5, although the values differ greatly among species (May \& Blaber 1989, Hamatsu et al. 2003).

Finally, our sampling did not cover the whole daytime distribution depth layer of Benthosema pterotum.

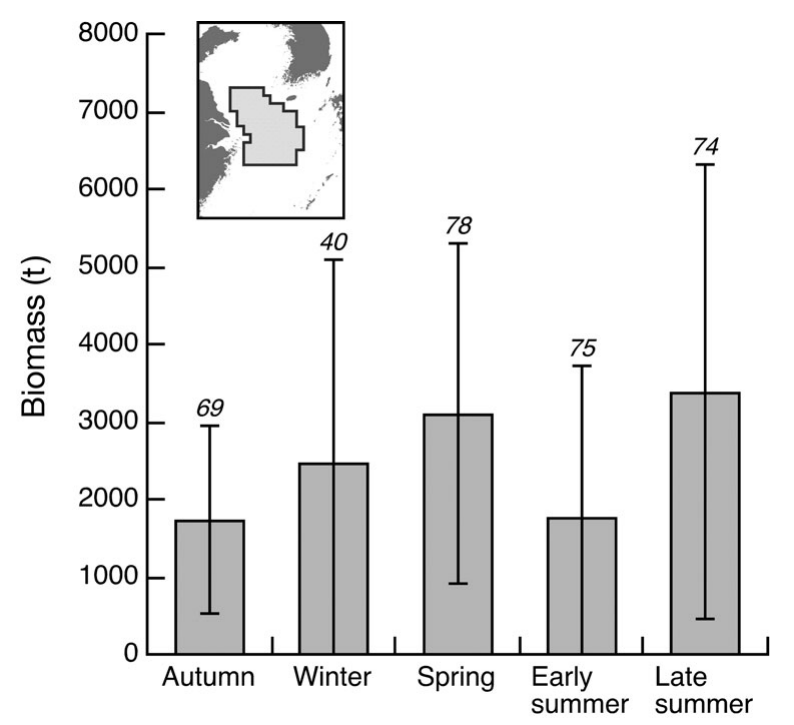

Fig. 7. Benthosema pterotum. Estimated biomass during the 5 cruises in the East China and Yellow seas. Error bars are $95 \%$ CI for the catches. The numbers above the bars are the numbers of stations analyzed. Area for which the biomass is calculated is also shown (inset)

Table 4. Benthosema pterotum. Range of corrected biomass (B) for each sampling period in the East China and Yellow seas

\begin{tabular}{|c|c|c|}
\hline Sampling season & Minimum & Maximum \\
\hline Autumn & 3926 & 19631 \\
\hline Winter & 5551 & 27757 \\
\hline Spring & 7048 & 35239 \\
\hline Early summer & 3958 & 19788 \\
\hline Late summer & 7689 & 38443 \\
\hline
\end{tabular}

The daytime main distribution of this species is up to ca. 5 to $10 \mathrm{~m}$ above the bottom, based on acoustic surveys in the study area (C. Sassa \& Y. Tsukamoto unpubl. data). Since the averaged height of our trawl net was $4.4 \mathrm{~m}$, the net covered ca. 44 to $88 \%$ of their distribution. 


\section{Horizontal distribution pattern}

Benthosema pterotum was the only myctophid species occurring in the benthopelagic layers in the shelf region of the ECS during the daytime in the present study. Even at night, no other myctophid species were collected in the shelf region where $B$. pterotum occurred abundantly, based on data from midwater trawl surveys in the epipelagic layers (C. Sassa \& Y. Tsukamoto unpubl. data). Although at least 25 species of myctophids have been collected abundantly in the continental slope region (ca. 200 to $1000 \mathrm{~m}$ depth) of the ECS where the Kuroshio main stream flows (Fig. 2a), B. pterotum is only rarely sampled there (Ozawa \& Tsukahara 1971, Kawaguchi 1977, Sassa et al. 2004). These data indicate that B. pterotum are restricted to shelf waters and do not occur in multispecies myctophid communities in deeper waters.

The physiological characteristics of Benthosema pterotum may be related to this unique distribution pattern. High densities of this species were observed in the low-salinity water of 32 to 33 (Fig. 6c), i.e. the lowest values among the myctophid species previously reported (e.g. Gjøsæter \& Kawaguchi 1980, Brodeur \& Yamamura 2005), which enables them to occur in the shelf region of the ECS. In addition, as discussed in the section 'Distribution in the shelf region', B. pterotum is considered to tolerate highly turbid waters in the shelf, unlike other myctophids, since most species are distributed in clear oceanic waters (Gjøsæter \& Kawaguchi 1980). Although highly turbid waters are considered to pose a number of stressors to benthopelagic populations of various fish species (e.g. Newcombe \& MacDonald 1991, Wilber \& Clarke 2001), there is no detailed information on how B. pterotum adapts to these conditions physiologically and ecologically.

The continual presence of Benthosema pterotum in the shelf region also suggests that there are selective advantages. The ECS receives large amounts of dissolved inorganic nutrients from the Changjiang River, which results in high primary productivity compared with areas outside of the shelf (Longhurst 2006). In the NECS, depth-integrated primary production is approx. 3 times higher on the shelf than in the slope region, although there is seasonal and local variability (Hama et al. 1997). In the central part of the NECS shelf where B. pterotum occurred abundantly in all seasons, high primary productivity has been measured throughout the year (Fei et al. 1994, Hama et al. 1997), which would provide good feeding conditions for B. pterotum. In the Arabian Sea, high concentrations of $B$. pterotum were observed especially in the highly productive areas (Gjøsæter \& Kawaguchi 1980).
Dense distributions of Benthosema pterotum were mainly observed in the area south of Cheju Island of the NECS, where a persistent cyclonic eddy occurs, regardless of the year, season, or oceanographic condition. Additionally, they occurred off the south coast of China of the SECS. In the present study, however, the distribution of $B$. pterotum between the area south of Cheju Island and the south coast of China was discontinuous especially in autumn, spring, and early summer (Fig. 4). Although no B. pterotum were collected in the south coast of China in late summer, this would be mainly due to the lack of sampling stations near the 70 to $80 \mathrm{~m}$ isobath where they occurred in the other seasons. The distribution pattern observed in the present study suggests the presence of an independent population completing its life cycle in the area south of Cheju Island, although there would be some exchange with the population off the south coast of China. For example, in winter, when the distribution of B. pterotum occurred in a slightly more westward area, the discontinuity between the population of the area south of Cheju Island and the south coast of China was not so clear compared to that in other seasons (Fig. 4), suggesting that some exchange between them might occur. In addition, larval transport by the Taiwan Warm Current (TWC) that flows northeastward in the southern part of ECS in summer (Ichikawa \& Beardsley 2002) (Fig. 2a) would be a potential connection between the north and south populations, but no information on the larval transport process of $B$. pterotum is available in the study area.

Our results were based primarily on data acquired during 1986 to 1991, since this is the best data set available to describe the spatio-temporal distribution of demersal and benthopelagic fishes in the ECS and YS. In the world oceans, there are few studies which describe the horizontal distribution of myctophid fishes among different seasons based on trawl sampling with such a fine-scale resolution and large spatial domain covered. Although the sampling area was more restricted, data from bottom trawl surveys during January to February from 1998 to 2001 showed a distribution pattern of Benthosema pterotum similar to the present results, i.e. they mainly occurred in the area south of Cheju Island and the south coast of China (C. Sassa unpubl. data). In addition, B. pterotum was usually collected in the area south of Cheju Island in spring, summer, and autumn during 2006 to 2009 (C. Sassa unpubl. data), corresponding with the occurrence pattern of the present study. The distribution pattern in the present study period (1986 to 1991) and in recent years (1998 to 2009) are considered to be approximately the same, although to confirm this, large-scale seasonal trawling surveys are needed in the future. 


\section{Daytime distribution depth}

An extensive diel vertical migration is one of the most remarkable features of most myctophid species. During the day most species are concentrated in the mesopelagic layer of 200 to $1000 \mathrm{~m}$ depth in the open waters, i.e. dim light condition (Gjøsæter \& Kawaguchi 1980, Brodeur \& Yamamura 2005). The mesopelagicboundary myctophid species usually occur in continental slope regions and around seamounts of ca. 200 to $1000 \mathrm{~m}$ bottom depth during the day (Kawaguchi 1977, Hulley \& Lutjeharms 1989, Reid et al. 1991, Hulley 1992, Gartner et al. 1997, 2008). In the Arabian Sea, Benthosema pterotum schools are found in the upper slope region, and the vertical distribution is characterized by 2 pelagic layers of 150 to $200 \mathrm{~m}$ and 250 to $350 \mathrm{~m}$ during daytime, whereas they migrate toward the surface to form a single layer in the upper $100 \mathrm{~m}$ depth at night (Gjøsæter 1984, Valinassab et al. 2007). However, in the ECS, the daytime habitat depth of $B$. pterotum was mainly 40 to $90 \mathrm{~m}$ depth, showing a significantly shallower daytime depth compared to those in other areas. This suggests a high degree of plasticity in distribution that may be dependent on local environmental conditions, thus there has to be a mechanism that enables this mesopelagic species to live in such a shallow area in the ECS.

\section{Distribution in the shelf region}

Generally, the light condition in the water column impacts the daytime distribution depth of mesopelagic fishes, and particular species are often considered to follow particular isolumes during migration (Clarke 1973, Kaartvedt et al. 1996, Griffiths et al. 2002). In the area to the south of Cheju Island, the bottom sediments are mainly composed of fine mud or clay-sized particles (Saito \& Yang 1994, Hamada 1998, Zhu \& Chang 2000) (Fig. 2b). A large part of the sediment is derived from present-day erosion of the ancient Huanghe submarine delta off Jiangsu Province (Milliman et al. 1985, Saito \& Yang 1994). The sediments are resuspended by the strong tidal current near the bottom (up to ca. 0.4 to $0.6 \mathrm{~m} \mathrm{~s}^{-1}$ ), producing highly turbid waters (Tanaka et al. 1987, Yanagi \& Inoue 1994, Hoshika et al. 2003). The highly turbid waters in the bottom layer are found between $30^{\circ}$ and $32^{\circ} \mathrm{N}$ and between $124^{\circ}$ and $126^{\circ} \mathrm{E}$ over the mud shelf region (Fig. 8) (Tanaka et al. 1987, Tanaka 1992). The turbidity increases greatly below the seasonal pycnocline during spring to late summer (Milliman et al. 1985, Tanaka et al. 1987, Hoshika et al. 2003) (Fig. 8), while it mixes vertically from surface to bottom in winter due to both tides and storms (Hoshika et al.
2003). Since penetration of sunlight is greatly reduced (Fig. 9), the dim light conditions in the bottom layer may enable Benthosema pterotum to live in such a shallow area of 40 to $90 \mathrm{~m}$ depths. At dawn, B. pterotum might actively swim into the highly turbid waters,
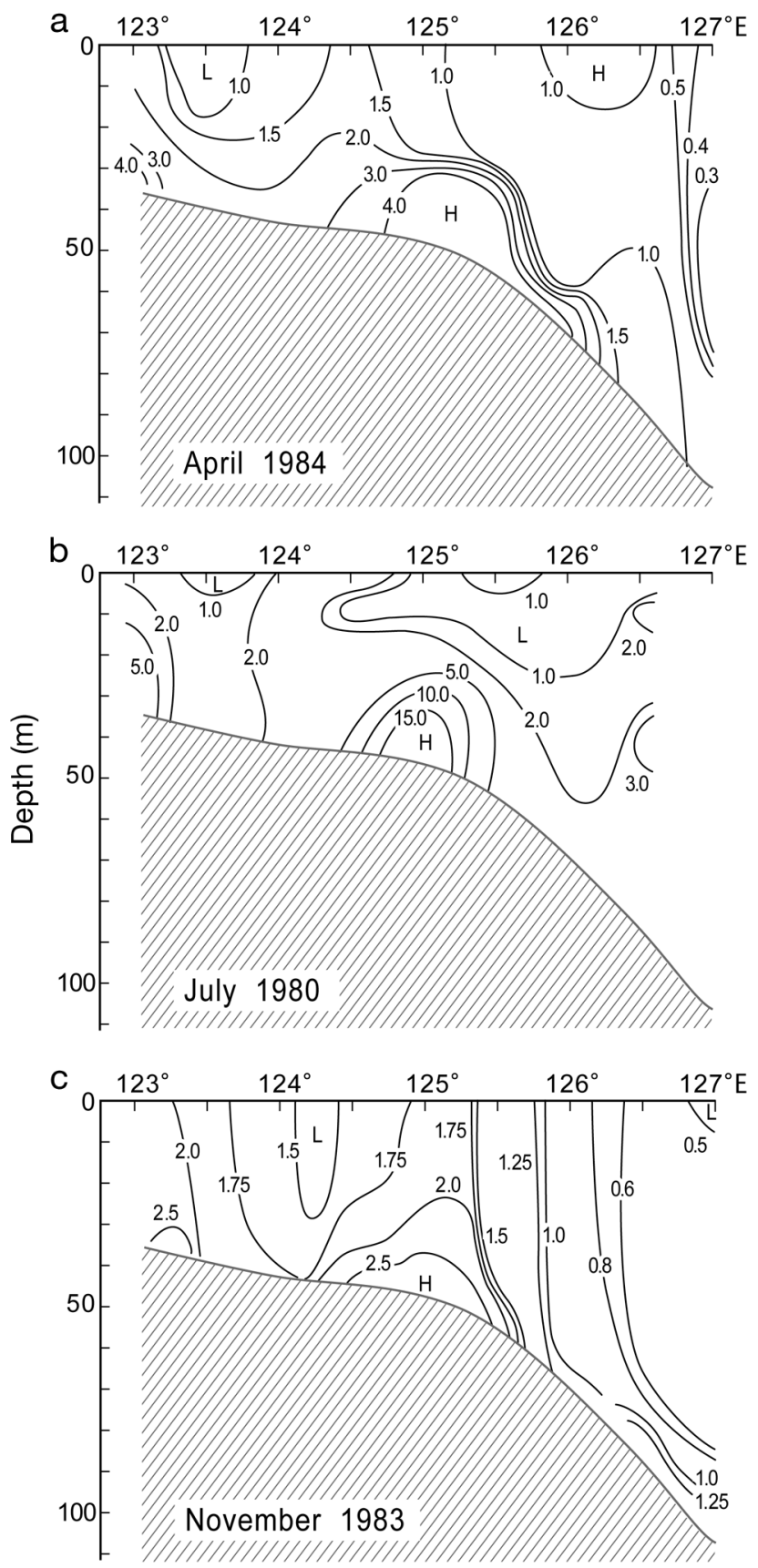

Fig. 8. Vertical profiles of turbidity along $31^{\circ} 30^{\prime} \mathrm{N}$ latitude in (a) April 1984, (b) July 1980, and (c) November 1983 (modified from Tanaka et al. 1987). Turbidity was expressed as dry weight of total suspended mater (TSM, $\mathrm{mg} \mathrm{l}^{-1}$ ) in July and beam attenuation coefficient $\alpha\left(\mathrm{m}^{-1}\right)$ in April and November. $\mathrm{H}$ : high turbidity; L: low turbidity 
without dispersing from the area south of Cheju Island. In some mesopelagic-boundary mesopelagic fishes, directed swimming behaviors are of great importance in maintaining the population in the continental slope and seamount regions (Wilson \& Boehlert 2004, Benoit-Bird \& Au 2006).

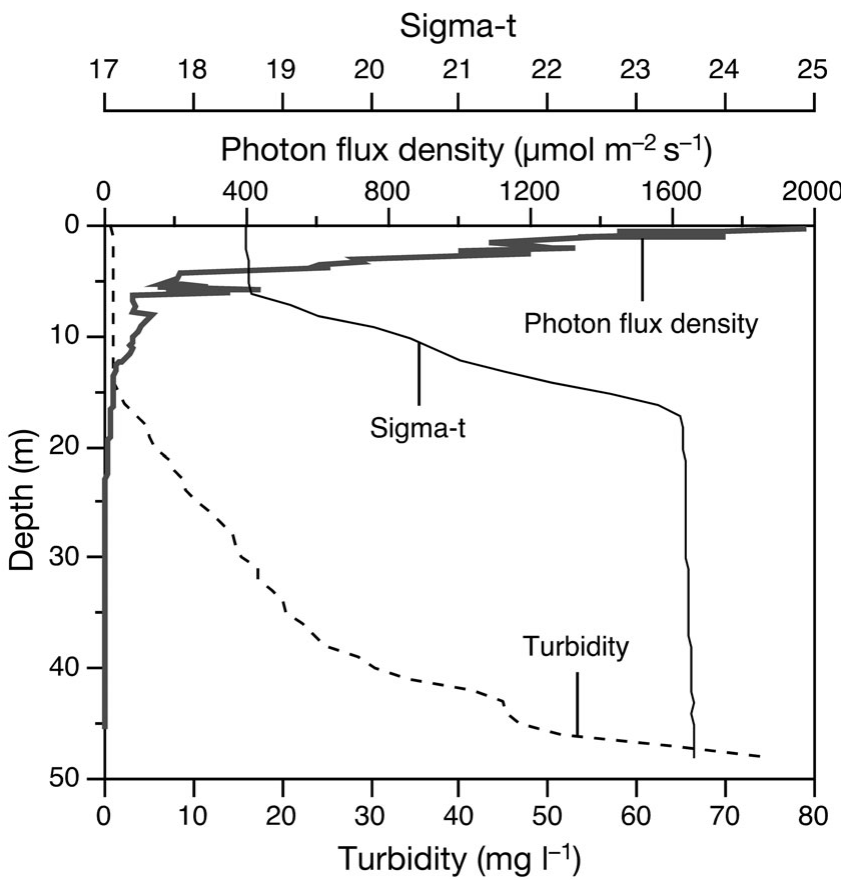

Fig. 9. Vertical profiles of sigma-t, turbidity, and light environment (photon flux density) in fine weather $(12: 00 \mathrm{~h})$ in the area south of Cheju Island $\left(31^{\circ} 77^{\prime} \mathrm{N}, 124^{\circ} 83^{\prime} \mathrm{E}\right)$ on 31 July 2003 (K. Okamura unpubl. data)
Direct comparison between distribution of Benthosema pterotum in the present study (Fig. 4) and turbidity can be made in autumn 1986 when Tanaka (1992) observed turbidity in our study area based on the oceanographic survey using another research vessel. High turbidity values $\left(>2 \mathrm{~m}^{-1}\right)$ were found in the bottom layers of the NECS between $30^{\circ}$ and $32^{\circ} \mathrm{N}$ and between $124^{\circ}$ and $126^{\circ} \mathrm{N}$ (Fig. 10), corresponding closely with the distribution of $B$. pterotum in autumn (Fig. 4). The turbidity in the bottom layers was also high in the area between $32^{\circ}$ and $34^{\circ} \mathrm{N}_{i}$ however, the salinity $(<32)$ was lower than the optimum value of B. pterotum (32 to 34 ) there (Fig. 4). The turbidity in the surface layers also tended to be high in the NECS, since water column mixing began in autumn (Tanaka 1992), but still the values were lower than in the bottom layers (Fig. 10).

Occurrence of Benthosema pterotum off the south coast of China can be explained by the same mechanism, since in this area: (1) the bottom sediments are mainly composed of mud, (2) upwelling and strong tidal currents occur along the south coast of China between $26^{\circ}$ and $30^{\circ} \mathrm{N}$, and (3) high-turbidity waters are observed (Hu 1984, Milliman et al. 1985, Tanaka 1992, Longhurst 2006) (Fig. 2). Mesopelagic squids (mainly, Abralia andamanica) were also caught abundantly in the benthopelagic layer in the area south of Cheju Island during our cruises (C. Sassa unpubl. data), and the dim light conditions would explain the occurrence in such a shallow area. It is reported that the depth of the DSL of the sternoptychid fish Maurolicus muelleri changed with the light conditions off Norway (Kaartvedt et al. 1996). Beneath clear waters on
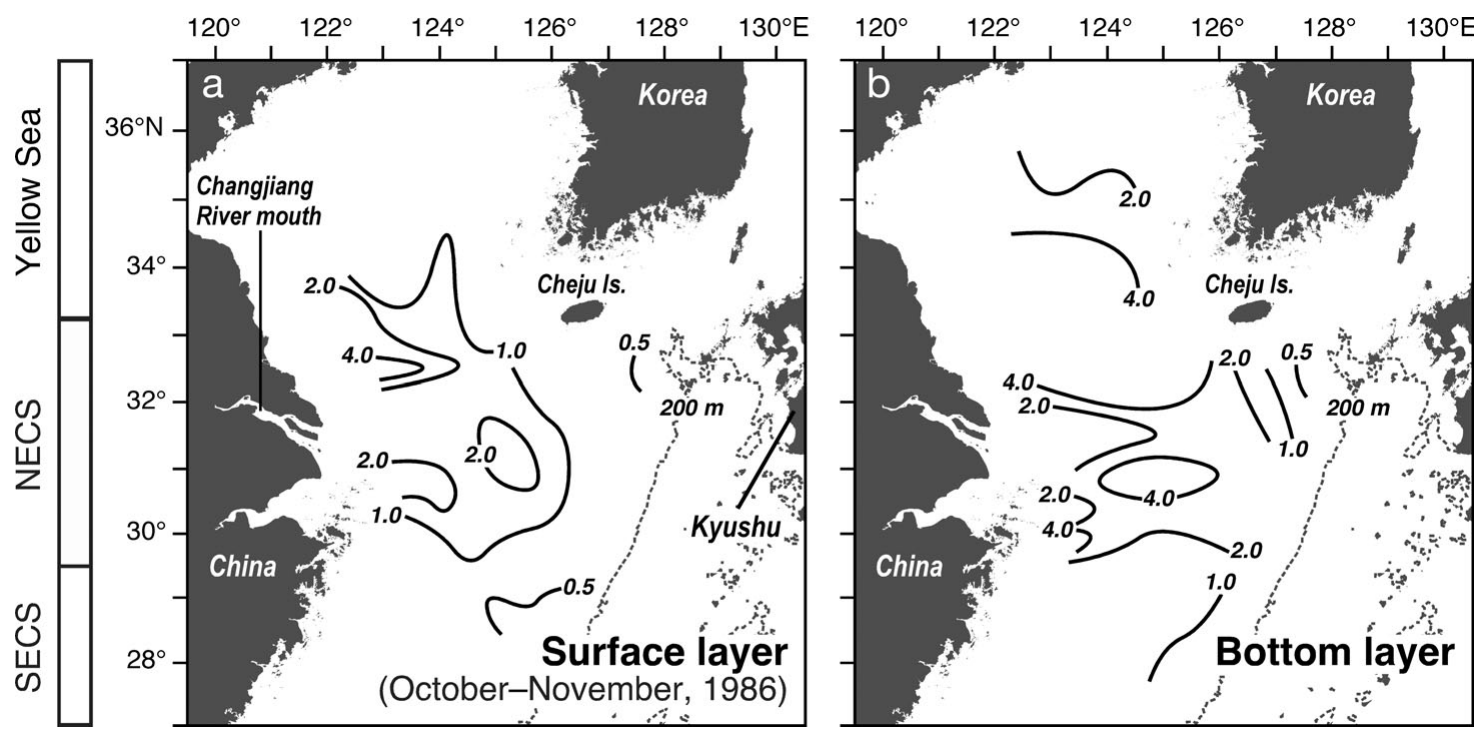

Fig. 10. Horizontal distribution of turbidity (solid line) at the (a) surface and (b) bottom layers in the East China and Yellow seas observed during 12 October to 3 November 1986 (modified from Tanaka 1992). Turbidity is expressed as beam attenuation coefficient $\alpha\left(\mathrm{m}^{-1}\right)$. NECS: northern East China Sea; SECS: southern East China Sea; dashed line: isobath 
the outer Norwegian shelf, they were located at ca. 150 to $200 \mathrm{~m}$ by day; on the other hand, they ascended abruptly by ca. $100 \mathrm{~m}$ across a front into water with less light penetration associated with increased chl a (Kaartvedt et al. 1996).

In the shelf region of the NECS, a small-scale distributional change in Benthosema pterotum was observed. That is, the distribution center of B. pterotum in the spring, early, and late summer samples was in a slightly more eastern area than in autumn and winter (Fig. 4). This might be related to the seasonal change of turbidity in the water column. During autumn to winter, the turbidity tends to increase throughout the water column in the NECS shelf, due to the seasonal vertical mixing (Milliman et al. 1985, Tanaka 1992, Hoshika et al. 2003), and the dim light conditions would be formed in a wide area of the shelf region. On the other hand, during spring to summer, the water column is stratified and highly turbid waters are found mainly in the bottom layer in the area south of Cheju Island where the bottom sediments are mainly composed of mud or clay (Tanaka et al. 1987) (Fig. 2b). This might be a reason why the distribution center of B. pterotum was slightly displaced eastward to just south of Cheju Island in the spring, early, and late summer samples. Additionally, the western side of the distribution of $B$. pterotum slightly shifted east or west among seasons, which potentially was influenced by salinity (cf. 32 isohaline in Fig. 4).

Few Benthosema pterotum were caught in the central part of the YS, although the same sediment types occur there as in the area south of Cheju Island and south coast of China (Saito \& Yang 1994, Hamada 1998) (Fig. 2a). The turbidity in the bottom layer of the central YS north of $34^{\circ} \mathrm{N}$ was observed to be lower than in the above areas (Milliman et al. 1986, Tanaka 1992) (Fig. 10), mainly because the effect of direct mixing by the seasonal monsoon is limited due to relatively deep depth (60 to $100 \mathrm{~m}$ ) and the tidal current is weak due to the existence of an amphidromic point in the central YS (Tanaka 1992, Yanagi \& Inoue 1994). In addition, the cold bottom waters $\left(<10^{\circ} \mathrm{C}\right)$, lower than the optimum habitat temperature of $B$. pterotum $\left(12\right.$ to $\left.24^{\circ} \mathrm{C}\right)$, was observed in all seasons in the central YS, although the salinity (>32) was in a range of the optimum habitat values (32 to 34 ). Both the relatively lower turbidity and the year-round presence of the cold bottom waters would prevent $B$. pterotum from entering into the YS and completing their life history.

\section{Biomass}

In the present study, the biomass of Benthosema pterotum in the area south of Cheju Island was esti- mated to range from ca. 3900 to 38400 t. Since $B$. pterotum is a major prey for commercially important pelagic and demersal fishes in the ECS (Mio et al. 1984, Baeck \& Huh 2003, Chiou \& Lee 2004, Chiou et al. 2006, Tang 2006, Yamada et al. 2007), the biomass of $B$. pterotum can be considered to represent an indicator of the prey condition for the commercial species. The biomass tended to increase from autumn to the following late summer, which is considered to link with the reproductive cycle, although seasonal sampling over a year is needed to confirm this pattern. Seasonal change of $B$. pterotum biomass is also reported in the Sea of Oman; the highest biomass estimates were obtained from mid-winter to the end of spring when their main spawning occurred (Gjøsæter 1984, Valinassab et al. 2007).

Acknowledgements. We are grateful to the captain, officers, and crew of the FTV 'Kumamoto-Maru' and FTV 'KaihoMaru' for their assistance with the field sampling. We also thank Dr. H. Fujita formerly of Seikai National Fisheries Research Institute who planned the sampling cruises. We thank the anonymous reviewers for their comments. Dr. K. Okamura of Seikai National Fisheries Research Institute provided data of vertical profiles of turbidity and light environment in the area south of Cheju Island.

\section{LITERATURE CITED}

Auster PJ, Griswold CA, Youngbluth MJ, Bailey TG (1992) Aggregations of myctophid fishes with other pelagic fauna. Environ Biol Fishes 35:133-139

Baeck GW, Huh SH (2003) Feeding habits of juvenile Lophius litulon in the coastal waters of Kori, Korea. J Korean Fish Soc 36:695-699

Beardsley RC, Limeburner R, Yu H, Cannon GA (1985) Discharge of the Changjiang (Yangtze River) into the East China Sea. Cont Shelf Res 4:57-76

Benoit-Bird KJ, Au WWL (2006) Extreme diel horizontal migrations by a tropical nearshore resident micronekton community. Mar Ecol Prog Ser 319:1-14

Brodeur RD, Yamamura O (eds) (2005) Micronekton of the North Pacific. PICES Sci Rep 30:1-115

Chiou WD, Lee LK (2004) Migration of kawakawa Euthynnus affinis in the waters near Taiwan. Fish Sci 70:746-757

Chiou WD, Chen CY, Wang CM, Chen CT (2006) Food and feeding habits of ribbonfish Trichiurus lepturus in coastal waters of south-western Taiwan. Fish Sci 72:373-381

Clarke TA (1973) Some aspects of the ecology of lanternfishes (Myctophidae) in the Pacific Ocean near Hawaii. Fish Bull US 71:401-434

> Dalpadado P (1988) Reproductive biology of the lanternfish Benthosema pterotum from the Indian Ocean. Mar Biol 98: 307-316

- Dalpadado P, Gjøsæter J (1988) Feeding ecology of the lanternfish Benthosema pterotum from the Indian Ocean. Mar Biol 99:555-567

De Forest L, Drazen J (2009) The influence of a Hawaiian seamount on mesopelagic micronekton. Deep-Sea Res I $56: 232-250$ 
Fei Z, Li B, Kuroda K (1994) Primary productivity in the northern East China Sea. In: Su J (ed) Proceedings of ChinaJapan joint symposium of the cooperative research on the Kuroshio. China Ocean Press, Beijing, p 453-469

- Garcia SM, Cochrane K (2005) Ecosystem approach to fisheries: a review of implementation guidelines. ICES J Mar Sci 62:311-318

Gartner JV Jr, Crabtree RE, Sulak KJ (1997) Feeding at depth. In: Randall DJ, Farrell AP (eds) Deep-sea fishes. Academic Press, London, p 115-193

> Gartner JV Jr, Sulak KJ, Ross SW, Necaise AM (2008) Persistent near-bottom aggregations of mesopelagic animals along the North Carolina and Virginia continental slopes. Mar Biol 153:825-841

Gjøsæter J (1984) Mesopelagic fish, a large potential resource in the Arabian Sea. Deep-Sea Res A 31:1019-1035

Gjøsæter J, Kawaguchi K (1980) A review of the world resources of mesopelagic fish. FAO Fish Tech Pap 193

Griffiths G, Fielding S, Roe HS (2002) Some observations of biophysical interaction in the ocean using high frequency acoustics. Proc Inst Acoust 23:189-195

> Hama T, Shin KH, Handa N (1997) Spatial variability in the primary productivity in the East China Sea and its adjacent waters. J Oceanogr 53:41-51

Hamada S (1998) Marine geological study of the submarine topography and shelf sediments of the East China Sea and the Yellow Sea. Bull Seikai Natl Fish Res Inst 76:27-94 (in Japanese with English abstract)

Hamatsu T, Yanagimoto T, Narimatsu Y (2003) Estimation of the fishing efficiency of kichiji rockfish, Sebastolobus macrochir, by comparison of the trawl survey and the submarine survey. JAMSTEC J Deep Sea Res 22:63-69 (in Japanese with English abstract)

Hoshika A, Tanimoto T, Mishima Y, Iseki K, Okamura K (2003) Variation of turbidity and particle transport in the bottom layer of the East China Sea. Deep-Sea Res II 50: $443-455$

Hu D (1984) Upwelling and sedimentation dynamics I. The role of upwelling in sedimentation in the Huanghai Sea and East China Sea - a description of general features. Chin J Oceanol Limnol 2:12-19

Hulley PA (1992) Upper-slope distributions of oceanic lanternfishes (family: Myctophidae). Mar Biol 114:365-383

Hulley PA, Lutjeharms JRE (1989) Lanternfishes of the southern Benguela region. Part 3. The pseudoceanic-oceanic interface. Ann S Afr Mus 98:409-435

Ibaibarriaga L, Irigoien X, Santos M, Motos L and others (2007) Egg and larval distributions of seven fish species in north-east Atlantic waters. Fish Oceanogr 16:284-293

Ichikawa H, Beardsley RC (2002) The current system in the Yellow and East China seas. J Oceanogr 58:77-92

Ishihara S, Kubota T, Yamada U (1995) Some morphological characteristics of a lanternfish, Benthosema pterotum (Alcock), in the East China and Yellow Seas. Bull Inst Ocean Res Dev Tokai Univ 16:1-12 (in Japanese with English abstract)

Kaartvedt S, Melle W, Knutsen T, Skjoldal HR (1996) Vertical distribution of fish and krill beneath water of varying optical properties. Mar Ecol Prog Ser 136:51-58

Kawaguchi K (1977) Micronekton community-community of myctophid fishes (family Myctophidae) in Suruga Bay, central Japan. In: Nishizawa S, Ishida R, Kawasaki T (eds) Communities and production in the sea. KoseishaKoseikaku, Tokyo, p 235-268 (in Japanese)

Kinzer J, Böttger-Schnack R, Schulz K (1993) Aspects of horizontal distribution and diet of myctophid fish in the Arabian Sea with reference to the deep water oxygen deficiency. Deep-Sea Res II 40:783-800
Koslow JA, Kloser RJ, Williams A (1997) Pelagic biomass and community structure over the mid-continental slope off southeastern Australia based upon acoustic and midwater trawl sampling. Mar Ecol Prog Ser 146:21-35

Longhurst A (2006) Ecological geography of the sea, 2nd edn. Academic Press, London

May JL, Blaber SJM (1989) Benthic and pelagic fish biomass of the upper continental slope off eastern Tasmania. Mar Biol 101:11-25

Milliman JD, Beardsley RC, Yang ZS, Limeburner R (1985) Modern Huanghe-derived muds on the outer shelf of the East China Sea: identification and potential transport mechanisms. Cont Shelf Res 4:175-188

Milliman JD, Zhao LF, Zheng YY, Limeburner TM (1986) Suspended matter regime in the Yellow Sea. Prog Oceanogr $17: 215-227$

Mio S, Tagawa M, Shinohara F, Yamada U (1984) Ecological study on the demersal fish associations in the East China Sea and the Yellow Sea, with reference to food relationships. Bull Seikai Reg Fish Res Lab 61:1-221 (in Japanese with English abstract)

Neira FJ, Keane JP (2008) Ichthyoplankton-based spawning dynamics of blue mackerel (Scomber australasicus) in south-eastern Australia: links to the East Australian Current. Fish Oceanogr 17:281-298

Newcombe CP, MacDonald DD (1991) Effects of suspended sediments on aquatic ecosystems. N Am J Fish Manage $11: 72-82$

Ozawa T (1986) Early life history of the family Myctophidae in the ocean off southern Japan. In: Ozawa T (ed) Studies on the oceanic ichthyoplankton in the western North Pacific. Kyushu University Press, Fukuoka, p 114-187

Ozawa T, Tsukahara H (1971) On the distribution of pelagic fish and juveniles in the East China Sea and its adjacent regions. Jpn J Ichthyol 18:139-146 (in Japanese with English abstract)

> Reid SB, Hirota J, Young RE, Hallacher LE (1991) Mesopelagic-boundary community in Hawaii: micronekton at the interface between neritic and oceanic ecosystems. Mar Biol 109:427-440

Saito Y, Yang Z (1994) The Huanghe River: its water discharge, sediment discharge, and sediment budget. J Sediment Soc Japan 40:7-17 (in Japanese with English abstract)

Sassa C, Kawaguchi K, Mori K (2004) Late winter larval mesopelagic fish assemblage in the Kuroshio waters of the western North Pacific. Fish Oceanogr 13:121-133

Sassa C, Yamamoto K, Tsukamoto Y, Konishi Y, Tokimura M (2009) Distribution and migration of age-0 jack mackerel (Trachurus japonicus) in the East China and Yellow Seas, based on seasonal bottom trawl surveys. Fish Oceanogr 18:255-267

Seikai National Fisheries Research Institute (2001) Biological and ecological characteristics of valuable fisheries resources from the East China Sea and the Yellow Sea: comparison between Chinese and Japanese knowledge. Seikai National Fisheries Research Institute, Nagasaki (in Japanese and Chinese)

Tanaka K (1992) Turbidity distribution in the East China Sea and the Yellow Sea in autumn 1986. Bull Nansei Natl Fish Res Inst 25:1-9 (in Japanese with English abstract)

Tanaka K, Uno S, Sakamoto W, Shirota A (1987) Turbid water area in the East China Sea. Bull Seikai Reg Fish Res Lab 64:13-23

Tang Q (ed) (2006) Chinese exclusive economic zone. Marine biological resources and habitat environment. Science Press, Beijing (in Chinese; title translated by C.S.)

Valinassab T, Pierce GJ, Johannesson K (2007) Lantern fish 
(Benthosema pterotum) resources as a target for commercial exploitation in the Oman Sea. J Appl Ichthyol 23: 573-577

Wilber DH, Clarke DG (2001) Biological effects of suspended sediments: a review of suspended sediment impacts on fish and shellfish with relation to dredging activities in estuaries. N Am J Fish Manage 21:855-875

Wilson CD, Boehlert GW (2004) Interaction of ocean currents and resident micronekton at a seamount in the central North Pacific. J Mar Syst 50:39-60

Yamada U, Tokimura M, Horikawa H, Nakabo T (2007) Fishes and fisheries of the East China and Yellow Seas. Tokai University Press, Tokyo (in Japanese)

Editorial responsibility: Nicholas Tolimieri, Seattle, Washington, USA
Yamamura O, Inada T (2001) Importance of micronekton as food of demersal fish assemblages. Bull Mar Sci 68:13-25 Yanagi T, Inoue K (1994) Tide and tidal current in the Yellow/East China Seas. Mer (Paris) 32:153-165

Yanagi T, Shimizu T, Matsuno T (1996) Baroclinic eddies south of Cheju Island in the East China Sea. J Oceanogr 52:763-769

Zhang J (1996) Nutrient elements in large Chinese estuaries. Cont Shelf Res 16:1023-1045

> Zhu Y, Chang R (2000) Preliminary study of the dynamic origin of the distribution pattern of bottom sediments on the continental shelves of the Bohai Sea, Yellow Sea and East China Sea. Estuar Coast Shelf Sci 51:663-680

Submitted: August 11, 2009; Accepted: February 3, 2010 Proofs received from author(s): May 13, 2010 